'We never recovered': The Social Cost of the 1951 New Zealand Waterfront Dispute and Supporting Strikes

In July 1951, 15,000 New Zealand watersiders, miners, freezing-workers and seamen returned to work after being locked-out or on strike, but their lives, and the lives of those dependent on their income, did not return to normal. For five months, most workers and their families had had to borrow money and leave bills unpaid in order to survive, and they needed to pay their debts. This article examines the social cost of the 1951 waterfront dispute. It concentrates on strike debt, and the long shadow that debt cast on family and community relationships. This article argues that many of the costs of an industrial dispute are not paid until after it ends, but in contrast to union's collective concern about costs during the dispute, costs after the dispute are privatised and treated as the concern of individual families.

In 1951, Maureen Martin's husband, a Wellington freezing-worker, was on strike for five months. Forty-eight years later, she recorded an interview with her 13 year-old grandson and described the impact on her family: "We never recovered from that strike, as far as money goes because we had to pay back money to Jack's mother that we had borrowed. See you were not paid a great wage in those days." In July 1951, 15,000 watersiders, miners, freezing-workers and seamen returned to work after being locked-out or on strike, but their lives, and the lives of those dependent on their income, did not return to normal. For five months workers and their families had borrowed money and left bills unpaid in order to survive without wages. This article will discuss the on-going cost of the 1951 waterfront lockout and supporting strikes, and will argue that debt and hardship in the aftermath of strikes and lockouts are an integral part of industrial struggle, which has received too little historical attention.

The 1951 waterfront dispute was one of the largest New Zealand industrial disputes. From the end of World War II New Zealand ports were sites of intense conflict between management and labour. ${ }^{2}$ Due to the importance of the waterfront to the economy, the state was actively involved in managing industrial conflict on the waterfront. The conflict came to a head in February 1951 in a dispute over wages. The New Zealand Waterfront Workers Union (NZWWU) refused overtime, because they were unsatisfied with the pay rise employers had offered. Employers responded by refusing to hire any worker unless they agreed to overtime. The state took over the negotiations, set the conditions for watersiders to return to work and passed draconian regulations. The Waterfront Strike Emergency Regulations criminalised watersiders' propaganda, marches and processions, and giving food or money to an NZWWU member. ${ }^{3}$ Approximately 7,000 miners, seamen and freezing workers went on strike in support of the watersiders and to oppose these regulations. ${ }^{4}$ The unions were defeated; at the beginning of July, workers returned to work on the government's terms. In Confrontation '51, Michael Bassett argued that the 1951 waterfront dispute helped make National the natural party of government for the next two decades. ${ }^{5}$ Bassett's argument

\footnotetext{
${ }^{1}$ Maureen Martin interview with Liam Martin, September 1999, Transcript, OHColl-0458, Oral History Centre, Alexander Turnbull Library (OHC-ATL).

2 Anna Green, British Capital, Antipodean Labour: Working the New Zealand Waterfront, 1915-1951 (Dunedin: University of Otago Press, 2001). Post-war conflict on the waterfront was not limited to New Zealand, see Colin Davis, Waterfront Revolts: New York and London Dockworkers, 1946-61 (Urbana: University of Illinois Press, 2003); L. J. Louis and Les Louis, “The Cold/Class War, and the Jailing of Ted Roach,” Labour History, no. 86 (2004).

3 'The Waterfront Strike Emergency Regulations 1951', Statutory Regulations 1951, Wellington, 1951, 65-73.

4 'Department of Labour Final Return of Strike or Industrial Dispute', 1951, AANK-W3285-7, Archives New Zealand (ANZ).

${ }^{5}$ Michael Bassett, Confrontation '51: The 1951 Waterfront Dispute (Wellington: Reed, 1972), 212.
} 
has had traction among other scholars. ${ }^{6}$ Historians have also discussed the industrial effects of 1951: Christine Meade described waterside workers' long struggle to regain national unity; Pat Walsh examined the legacy of 1951 for the arbitration system and Cybele Locke discussed the role that activists who had been involved in the dispute played in other parts of the union movement. ${ }^{7}$ Melanie Nolan argued that the reliance on other family members' income during the dispute and the defeat of the NZWWU weakened the breadwinner wage system. ${ }^{8}$ The legacy of the dispute in parliament, trades halls and workplaces has been covered, but its aftermath in homes and communities has received little historical attention.

More widely, labour historians have considered the industrial effects of strikes and lockouts as integral to their history, but rarely made the same arguments about the social effects. David Camfield presented the rationale for this approach in his assessment of a recent Canadian health workers' strike: "A central question in any assessment of the HEU strike is what it represented for the working-class movement". ${ }^{1}$ Since 2006, fifteen articles in Labour History have focused on strikes or lockouts. Most of them do not discuss the aftermath, and if they mention it at all they focus on the industrial legacy. ${ }^{9}$ When historians have addressed the social costs of an industrial dispute, they have done so in ways that underscore the marginalised nature of those questions. For example, Steven Thompson and Sue Bruley both noted that financial stress in mining communities in the 1926 miners' lockout in the UK was exacerbated because many families had not repaid their debts from the 1921 lockout, but historians have not treated debt from the

${ }^{6}$ Robert Chapman, "From Labour to National," in The Oxford History of New Zealand, ed. W. H. Oliver (Wellington: Oxford University Press, 1981); Barry Gustafson, "The National Governments and Social Change (1949-1972)," in The Oxford Illustrated History of New Zealand, ed. Keith Sinclair (Auckland: Oxford University Press, 1990); Tom Brooking, The History of New Zealand (Westport: Greenwood Press, 2004). ${ }^{7}$ Christine Meade, "New Zealand Waterfront Unions, 1951-1967: A Study of the Repercussions of the 1951 Strike on the Wharf Unionists, and of Union Organisation from the Defeat of the N.Z.W.W.U. Until the Formation of the New Zealand Federation of Watersiders," (MA, University of Otago, 1980); Pat Walsh, "The Legacy of '51," in The Big Blue: Snapshots of the 1951 Waterfront Lockout, ed. David Grant (Christchurch: Canterbury, 2004); Cybèle Locke, Workers in the Margins: Union Radicals in Post-War New Zealand (Wellington: Bridget Williams Books, 2012). 36.

${ }^{8}$ Melanie Nolan, “The Women Were Bloody Marvellous’: 1951, Gender and New Zealand Industrial Relations," Historical Studies in Industrial Relations, no. 16 (2003).

${ }^{9}$ Mark Westcott, "One of the Boys or the Common Good?: Workplace Activism in the NSW Branch of the Federated Engine Drivers and Firemens Associations," Labour History, no. 91 (2006); John Tully, “"Nothing but Rebels': Union Sisters at the Sydney Rubber Works, 1918-42," Labour History, no. 103 (2012); Robert Tierney, “The New South Wales Railway Commissioners' Strategic Pre-Planning for the Mass Strike of 1917," Labour History, no. 98 (2010); Danielle Thornton, “We Have No Redress Unless We Strike’: Class, Gender and Activism in the Melbourne Tailoresses' Strike, 1882-83,” Labour History, no. 96 (2009); Judith Smart, "Respect Not Relief: Feminism, Guild Socialism and the Guild Hall Commune in Melbourne, 1917," Labour History, no. 94 (2008); Michael Quinlan, "The Low Rumble of Informal Dissent: Shipboard Protests over Health and Safety in Australian Waters, 1790-1900," Labour History, no. 102 (2012); Rory O’Malley, “The Eclipse of Mateship: The 'Wide Comb Dispute’ 1979-85,” Labour History, no. 90 (2006); Patrick O’Leary and Peter Sheldon "Strategic Choices and Unintended Consequences: Employer Militancy in Victoria's Meat Industry, 1986-93," Labour History, no. 95 (2008); Ashley Lavelle, "Under Pressure: The Whitlam Labor Opposition and Class Struggle, 1967-72," Labour History, no. 96 (2009); Charles Fahey and John Lack, "Silent Forms of Coercion': Welfare Capitalism, State Labour Regulation and Collective Action at the Yarraville Sugar Refinery, 1890-1925," Labour History, no. 101 (2011); Nick Dyrenfurth, “'A Terrible Monster': From Employers to Capitalists in the 1885-86 Melbourne Wharf Labourers' Strike," Labour History, no. 94 (2008); Sandra Cockfield, "Mobilising at the Workplace: State Regulation and Collective Action in Three Workplaces, 1900 to the 1920s," Labour History, no. 93 (2007); Robert Bollard, "The Active Chorus': The Great Strike of 1917 in Victoria," Labour History, no. 90 (2006); David Baker, "A Tale of Two Towns: Industrial Pickets, Police Practices and Judicial Review," Labour History, no. 95 (2008); Paul Robert Adams and Erik Eklund, "Representing Militancy: Photographs of the Broken Hill Industrial Disputes, 1908-20,” Labour History, no. 101 (2011). 
1921 lockout as important in itself. ${ }^{10}$ Timothy Minchin's article on the International Paper Company Strike of 1987-88 focused on the employer's decision to permanently replace many workers and so he discussed the impact of unemployment on workers and their families. ${ }^{11}$ The social aftermath of strikes and lockouts has, at best, been on the periphery of their histories.

\section{Strike Debt}

For five months nearly 15,000 workers did not receive wages. The state estimated that, without considering overtime or special rates, watersiders would have earned an average of $£ 180$, seamen $£ 200$ and miners $£^{220}$. In total, watersiders lost almost $£ 1.5$ million pounds. ${ }^{12}$ Historians have discussed how families survived; Michael Bassett described three strategies: other employment (for both watersiders and their family members), relief committees, and debt. ${ }^{13}$ This section will demonstrate that neither employment nor aid from relief committees were adequate substitutes for the wages families lost and that most families had to go into debt.

Contrary to Bassett's suggestion, large numbers of watersiders did not get other work. ${ }^{14}$ Union members, the press and the government all treated getting paid work during those months as a sign that a worker was withdrawing from the dispute. ${ }^{15}$ As a watersider's child understood it: "I got the impression that if you took other work, you were a scab." 16 The chair of the Auckland branch told a union member who travelled to Taupō to start a business: "he left the Union during a critical time and if every man did this there would be no union" ${ }^{17}$ Some workers did take other work, either because they received permission from the union due to exceptional circumstances, or because they withdrew from the dispute, but in most places this was an extremely rare survival strategy. ${ }^{18}$ Letters to the Auckland branch of the NZWWU from those seeking clearance to get other work suggest that debt was a more acceptable survival strategy than leaving the union. ${ }^{19}$

\footnotetext{
${ }^{10}$ Sue Bruley, "The Politics of Food: Gender, Family, Community and Collective Feeding in South Wales in the General Strike and Miners' Lockout of 1926," Twentieth Century British History 18, no. 1 (2007): 63; Steven Thompson, "That Beautiful Summer of Severe Austerity: Health, Diet and the Working-Class Domestic Economy in South Wales in 1926," The Welsh History Review 21, no. 3 (2003): 564.

11 Timothy Minchin, “Labor's Empty Gun': Permanent Replacements and the International Paper Company Strike of 1987-88," Labor History 47, no. 1 (2006): 30.

${ }^{12}$ Department of Labour, 'Schedule of the Time and wages Lost workers Involved in Waterfront Dispute', 1951, AANK-W3285-7, ANZ.

${ }^{13}$ Bassett, Confrontation, 138-139. See also, Scott, 151 Days, 165-173.

${ }^{14}$ Bassett, Confrontation, 139. Bassett footnotes this claim to an article in the Herald, but police sources demonstrate that they were the source for this article, and that it was untrue: Report of Dave Patterson, Wellington, 1 April 1951, ADMO-21007-W5595-25/9/20/12, ANZ.

${ }^{15}$ Minutes of Meeting of Unions Directly Involved in Waterfront Dispute, 13 June 1951, Box 1, Barnes Papers, Auckland University Library (AUL); Huntly Coalfields Oral History Project, OHC-ATL; 'Many waterside strikers now in full-time jobs in various other industries', 5 April 1951, Dominion, ADMO-2100725/9/20/6 Part 1; Report of Dave Patterson, Wellington, 1 April 1951, ADMO-21007- 25/9/20/12; Report of E.G. Ward, Lyttelton, 1 April 1951 and Report of Duncan Wilson, Oamaru, 31 March 1951, ADMO-21007-5/9/20/2 Part 1; Report Bluff, 2 May 1951, ADMO-21007-25/9/20/3, ANZ.

${ }^{16}$ Maureen Fairey interview with Grace Millar, 5 July 2010, interviews in this collection are in the author's possession and will be deposited in the OHC-ATL.

${ }^{17}$ NZWWU Auckland Branch, Minutes of Special Meeting of Executive \& Chairmen of Committees, 6 April 1951, 94-106-11/01, Roth Papers, ATL.

${ }^{18}$ For an example of how rare see, Report of E. G. Ward, Lyttelton, 1 April 1951, ADMO-21007-

25/9/20/2, Part 1, ANZ.

${ }^{19}$ See for example, NZWWU Auckland Branch, Minutes of Special Meeting of Executive \& Chairmen of Committees, 21 April 1951, 5 June 1951, 94-106-11/01; N. Coole to R. Jones, 5 June 1951, 94-106-11/04, Roth Papers, ATL.
} 
Families could receive some funding from union relief, but union's funds were restricted. When the NZWJWU was deregistered, the Public Trust confiscated $f_{6} 60,854$ from the NZWWU, two thirds from the national office funds and the rest from individual branches, which was a substantial attack on the union's ability to fight the dispute. ${ }^{20}$ While the NZWWU national office did receive aid from overseas unions, transferring these funds was difficult in light of the emergency regulations. ${ }^{21}$ Branches did have other sources of funds, but the amount they collected - while substantial - in no way compensated for the loss of income. The Auckland branch spent an average of just 15 shillings per family per week on relief. ${ }^{22}$ Dick Scott suggested that unions spent $£ 150,000$ on relief, but his figures include an overestimation of how much Australian money reached relief committees. ${ }^{23}$ However, even if Scott's figures were accurate, $£ 150,000$ was only $£ 10$ per locked-out or striking worker for five months. Without overtime, watersiders earned $£ 8 / 10$ a week. ${ }^{24}$ While the amount donated was substantial, when divided among 15,000 workers it was inadequate to meet even the most basic needs.

Locked-out and striking workers and their families did have other strategies available to them. There is substantial evidence that watersiders' wives routinely got other work. ${ }^{25}$ However, women earned about half of what their husbands had. ${ }^{26}$ In addition, families received aid from neighbours and kin, hunted, and went without. ${ }^{27}$ But workingclass wages in 1951 were not high and there was not much give in a family budget.

Families needed their gardens just to get by - gardens could not solve the problem of food for five months. ${ }^{28}$ However, grocers did not expect immediate payment to provide goods. ${ }^{29}$ Watersiders and their families did not need to go out and actively borrow money, which was one of the reasons that debt was such a widely used survival strategy. When Maureen Martin discussed her situation with her grocer, the grocer made it clear that many customers did not pay their bills on time. ${ }^{30}$ The files of SAC and Farmers

\footnotetext{
20 'Summary', Department of Labour, appointment of a receiver, AANK-W3285-7, ANZ.

${ }^{21}$ Jim Healy, General Secretary Waterside Workers' Federation of Australia, To all branches and federal councillors, 24 July 1951, Box 1, Vault 156, Barnes Papers, AUL; Report of Detective Sergeant R. Jones, relative to: Edward Albert Napier - Vide Attached no. 3272, ADMO-21007-W5595/1-25/9/20, ANZ; Fred Rix interview with Nicola Lovett, 26 November 2011, 2010.130.1, Huntly Coalfields Museum.

${ }^{22}$ E. Williamson, Relief Committee Report, July 1951, 94-106-11/06, Roth Papers, ATL.

${ }^{23}$ Scott, 151 Days, 173. Just over $£ 20,000$ was distributed from national office to the branches during the dispute, not the $f_{50,000}$ Scott suggested, [Rough Accounts], New Zealand Waterside Workers Union, 1951, 88-311, Hill Papers, ATL.

24 Bassett, Confrontation, 68.

${ }^{25}$ Report of A. Johnston, Greymouth, 30 March 1951, ADMO-21007-W5595-25/9/20/13, ANZ; Andrea Hotere, “The 1951 Waterfront Lockout in Port Chalmers," (BA Hons thesis, University of Otago, 1989), 92.

${ }^{26}$ Northern Taranaki, Wellington, Canterbury and Otago and Southland Cleaners, Caretakers, Lift Attendants and Watchmen Award 1950, 3 May 1950; New Zealand Clothing-Trade Employees Award 1950, 8 September 1950, New Zealand Awards Agreements \& c., made under the Industrial Conciliation and Arbitration Act, Apprentices Act and the Labour Disputes Investigation Act, 1950, Vol. 50, 429, 1063.

${ }^{27}$ See, for example, Alison Pitt, interview with Jamie MacKay, 3 April 1992, OHInt-0020/17, OHC-ATL; Tom and Pat Gregory interview with Grace Millar, 20 December 2010; Joseph Kereopa interview with Jamie Mackay, 27 February 1992, OHInt-0020/07, OHC-ATL; Jenny Cameron [pseudonym] interview with Grace Millar, 17 April 2012. For more information see Grace Millar, 'Families and the New Zealand 1951Waterfront Dispute', (PhD, Victoria University of Wellington, 2014).

${ }^{28}$ Kate Jordan, ‘Golden Weather Gardening: New Zealand Home Sections, 1945-1970', (MA, University of Auckland, 2009), 59-62.

${ }^{29}$ See, Norah Holland, 'Some Aspects of Home-Making', (Master of Home Sciences thesis, University of Otago, 1950).

${ }^{30}$ Maureen Martin interview with Liam Martin, September 1999, Transcript, OHColl-0458/1, OHC-ATL.
} 
show that some level of late payment of rent and hire purchase was normal. ${ }^{31}$ Families had to, and could, postpone paying some of their bills and therefore go into debt; lockedout and striking workers could not get other work and the substantial sums union relief committees put together were inadequate to make up for lost wages.

Debt, particularly debt incurred by not paying bills, was part of NZWWU's strategy for workers' survival. Union branches knew that their members were not paying all their bills and did not leave workers' access to credit to chance. In 1949, during a short-lived dispute on the Auckland waterfront, the first action of the relief committee was to approach stores that offered hire purchase to their customers and ask for credit for watersiders. ${ }^{32}$ In 1951, the Auckland relief committee acted on behalf of union members in ensuring that state housing tenants would not be pushed for rent during the lockout. ${ }^{33}$ Decades later Johnny Mitchell, who was on the Auckland branch committee, could still remember the response he received:

Farmers Trading Company as far as I can remember had a fairly good reputation, Smith and Brown was another one that were fairly liberal, the bad ones I can remember - Bond and Bond they weren't very good, Nathan Brothers. [...] There were a number of hire purchase firms that were quite compassionate to watersiders, there were one or two that were not very compassionate, but generally speaking we didn't do too bad among those people. ${ }^{34}$

On 13 June 1951, the Wellington branch of the NZWWU asked the Wellington City Council not to disconnect the electricity of union members who were behind on payments. ${ }^{35}$ This is further evidence that branches knew that a significant portion of their members were not paying their bills, and actively tried to organise credit.

Oral histories about 1951 do not often directly discuss how people survive, but those that do suggest that credit was central. ${ }^{36}$ Maureen Martin's grocer told her to order as normal and repay him afterwards. ${ }^{37}$ Russell French, a locked-out Wellington watersider, was living in a block of housing on Molesworth St in Wellington that was mostly rented to watersiders. When explaining how he survived he stated: "No one got put out of that place". ${ }^{38}$ Ian Church, whose father was a locked-out watersider in Port

${ }^{31}$ Legal - Summonses - Return of eviction orders for Minister of Housing, AELE-19203-SAC1/47-8.4.2, ANZ; Irvine Hire to Hire Purchase Department Farmers Trading Company, 4 June 1946; Mrs D. Johnstone to Farmers Trading Company, 16 December 1940, Box 7 (41), 91/37, Farmers Trading Company Papers, Auckland Museum.

32 Auckland Lockout Minutes, 1949, 94-106-11/09, Roth Papers, ATL.

${ }^{33}$ NZWWU Auckland Branch, Minutes of Special Members Meeting, 6 March, 8 March, 14 May 1951, $94-$ 106-11/01, Roth Papers, ATL.

${ }^{34}$ John James Mitchell interview with Douglas Crosado, Ray Grover and Bert Roth, 1977-1988, OHInt0219/1, OHC-ATL. Oral histories of Wellington relief committee members include similar accounts: Trade Union History Project, 'A Dissenting New Zealand: a Seminar on the Life of Rona Bailey', December 1993, audio recording, OHC-01451; Ted Thompson interview with Cath Kelly, 1990, OhInt0112/3, OHC-ATL.

${ }^{35}$ Unfortunately no further information, such as how many members were behind on their bills is available. General Meeting of the Council, 13 June 1951, Wellington City Council Minute Books, Volume 59, 00166:0:57, Wellington City Archives.

36 There are over 50 oral history interviews with people who were involved in the dispute in the ATL, smaller collections in the Huntly Museum and in private hands, and I completed a project of 20 interviews for this research. However, few of these interviews discuss how families survived directly; I have used the interviews that do in this discussion.

${ }^{37}$ Maureen Martin interview with Liam Martin, September 1999, Transcript, OHColl-0458/1, OHC-ATL.

${ }^{38}$ Russell French interview with Grace Millar, 6 January 2011. 
Chalmers, emphasised this point: "Anyone in Port will tell you that the local grocer and butcher carried a lot of people through " 51 . So there were often quite large bills owing." 39 Kevin Ford described his father, a Bluff Watersider, telling him that half the port was carried by their local grocer. ${ }^{40}$ In their oral histories, interviewees do not just talk about their own use of credit, but also indicate that credit was a standard survival strategy.

Oral history evidence from those who described themselves as not going into debt reinforces the importance of credit for most families. Throughout his interview Tom Gregory emphasised that he did not believe in debt, had never gone into debt, and contrasted his behaviour with other people he knew who put goods on hire purchase; he presented not going into debt as part of his identity. However, he said that his landlady had told him that they should only pay their rent when they could. ${ }^{41}$ So even though he did not classify it as debt, his landlady's credit was central to his family's survival. The only evidence from a family that appears not to have gone into debt at all comes from interviews with Ted and Ida Thompson. ${ }^{42}$ Their mortgage payments were not large, Ida took paid work, they received money from Ida's parents, food from their neighbours and they spent all their savings. ${ }^{43}$ Their experience demonstrates the range of resources required to avoid debt.

The institutions that extended credit have not left archival records of this debt. Small institutions, such as landlords and grocers, have not deposited their records in archives. ${ }^{44}$ The State Advances Corporation (SAC) ran state housing and does have archives; these do not directly address the dispute, but do demonstrate the normal practice of SAC around rent arrears and evictions. ${ }^{45}$ An eviction for unpaid rent was a serious step for SAC to take - it required the written permission of the Minister of the time, Jack Marshall..$^{46}$ In the 1949 calendar year, only nine people were evicted from state houses. ${ }^{47}$ One woman owed $f, 78 / 12 / 0$; she was 39 weeks behind on the rent. In court she agreed to pay it back at a rate of five shillings a week, an agreement she kept to 'fairly regularly' according to SAC staff, and this was enough for her to avoid eviction. ${ }^{48}$ While SAC sources cannot provide information on how many watersiders went into debt, it can demonstrate that watersiders could go into debt by not paying their rent without being evicted.

Definitive information about how many workers used debt during the dispute is not available, however all the evidence that is available suggests that going into debt was widespread, and paying off debt after 1951 was a common experience for those who went on strike or were locked out. Other funding to make up for the massive hole in family budgets was inadequate and union sources indicate that credit was an active union strategy for survival. Oral histories further suggest that credit was a normal way of coping and relatively easy to obtain. The relative ease with which working-class families accessed

\footnotetext{
${ }^{39}$ Ian Church, interview with Grace Millar, 11 February 2011.

${ }^{40}$ Kevin Ford interview with Grace Millar, 13 February 2011.

${ }^{41}$ Tom and Pat Gregory interview with Grace Millar, 20 December 2010.

${ }^{42}$ As many of those interviewed did not directly address how they survived, for many of the interviews it is impossible to tell whether the interviewee went into debt or not.

${ }^{43}$ Ted Thompson and Ida Thompson interviews with Cath Kelly, 1990, OhInt-0112/3; Ida Thompson interview with Kerry Taylor, 1995, Ted Thompson interview with Kerry Taylor, 1995, OHColl-0861, OHC-ATL.

${ }^{44}$ I have searched the ATL for relevant archives. I have also made special inquiries of the libraries in port towns.

${ }^{45}$ See the following files: AELE-19207-SAC10-5; AELE-19203-SAC1/47-8.4.2; AELE-19203-SAC1

17/5/76/1-Part 2, ANZ.

${ }^{46}$ Circular S.A.C., 1951/26, 17 July 1951, AELE-1927-SAC10-5, ANZ.

47 'Memorandum for Minister for State Advances', 6 August 1950, AELE-19203-SAC1/47-8.4.2, ANZ.

${ }_{48}$ Memorandum, SAC of New Zealand Auckland Office, 4 August 1950, AELE-19203-SAC1/47-8.4.2, ANZ.
} 
credit is also shown in institutional records. While there is not enough evidence to be certain about the exact number of people involved - all the available evidence suggests that it was a majority experience.

Many individuals, companies and institutions lent money to locked-out and striking workers, but most of them have left no records. The best record for the size of workers' debt is the Seamen's union records. Striking seamen were in a different position from other locked-out and striking workers. When seamen went on strike and left their ships, they were walking away from their beds and they were carrying the wages from their latest voyage. ${ }^{49}$ The Seamen's Union called on members who had savings to lend that money to the relief effort and paid Post Office Savings Bank rates of interest. Then the union lent this money to members who needed relief at the same interest rate. ${ }^{50}$ The Seamen's Union Records contain a repayment book from Auckland. R. Blackburn recorded the highest repayments; he repaid $f 40$, which was six weeks to two months of a seaman's wage. ${ }^{51}$ Other seamen repaid significant amounts: 22 individuals repaid more than $£ 20$, 46 between $£ 10$ and $£ 20$, and just over a hundred repaid less than $£ 10 .^{52}$ These records are partial, but give a sense of how substantial some workers' debts were, particularly when compared to their income. They also show how varied the size of workers' debt was, and their ability to pay it off.

The typical size of a bill that went unpaid is the other best source for families' level of debt by July 1951. In 1951, SAC rent for a five room house was between $f_{1} 1 / 14 / 0$ and $f^{2 / 3} / 6$ per week. ${ }^{53} \mathrm{~A}$ family that had been unable to pay rent of $f^{2}$ per week during the dispute would owe $£ 40$ by July, which was the equivalent of 5 weeks' wages. ${ }^{54}$ N. Coole, an Auckland watersider, had hire purchase payments of $£^{2} / 17 / 0$; if he did not pay this for the duration of the dispute then he would owe $f, 57$, plus interest, which would have been two months' wages. ${ }^{55}$ The Seamen's Union files demonstrate, and the size of bills that were left unpaid suggest, that many workers' owed more than they could earn in a month as a result of the dispute.

\section{Repaying Debt}

There are even fewer sources on repaying debt than on the level of families' debt in the first place and the same mixture of archival and oral history sources are the only way to reconstruct how debt shaped families' lives. The first hurdle for most watersiders in repaying their debt from the lockout was finding new work. The government won the

\footnotetext{
${ }^{49}$ For example, Keith Roberts interview with Grace Millar, 19 June 2011.

50 'Statement made by Frederick Charles O’Connor', 9 July 1951, AANK-W32853-7, ANZ; Minutes of Lyttelton Seamen's Union Special Meeting, 17 April 1951, Box 26, D-8, Seamen's Union Auckland Branch records, AUL.

${ }^{51}$ Auckland Seamen's Strike Committee - Financial records, 80-307-22/03, New Zealand Seamen's Union Records, ATL; New Zealand Seamen Award, 16 December 1950, New Zealand Awards Agreements \& c., made under the Industrial Conciliation and Arbitration Act, Apprentices Act and the Labour Disputes Investigation Act, 1950, Vol.50, 3651.

52 Auckland Seamen's Strike Committee - Financial records, 80-307-22/03, New Zealand Seamen's Union Records, ATL.

53 'State housing new and old - increase of rental charges' Appendix to head office circular memorandum, 31 March 1950, AELE-19203-SAC1/189-35.88-Part 2, ANZ.

${ }^{54}$ For examples, Wellington City Council Labourers Award, 13 September 1950, New Zealand Awards Agreements \& c., made under the Industrial Conciliation and Arbitration Act, Apprentices Act and the Labour Disputes Investigation Act, 1950, Vol.50, 1382-3; New Zealand (except Westland and Canterbury) General Warehousemen (other than soft-goods) Amendment of Award, 12 April 1949, New Zealand Awards Agreements \& c., made under the Industrial Conciliation and Arbitration Act, Apprentices Act and the Labour Disputes Investigation Act, 1949, Vol.49, 1261.

${ }^{55}$ N. Coole to R. Jones, 5 June 1951, 94-106-11/04, Roth Papers, ATL.
} 
dispute by finding replacement waterfront workers. Only 2,200 former members of the union returned to work on the wharf after the dispute was over; the other 6,200 had to find other work. ${ }^{56}$ Access to employment on the wharf after the dispute varied significantly between ports; in Auckland existing watersiders were very effectively blacklisted from the waterfront for life, on the West Coast all watersiders returned to their jobs. ${ }^{57}$ Unemployment was very low in 1951; most workers found other work easily and many employers could not afford to black-list workers who had been involved in the dispute. Three groups of workers were vulnerable to blacklisting: those in small ports, those who took leadership positions during the dispute, and those seeking work in a small industry. These workers had to move, or start a small business in order to get new employment. ${ }^{58}$ The impact of having to find new work was unevenly distributed. Many workers were not able to earn as much money in their new jobs as they had previously, as other industries did not have the same level of overtime. For example, Ian Church's father, who had been a Port Chalmers watersider, took work as a foreman at the dry dock in after the dispute, but Maureen Fairey's father, who had been an Auckland watersider, never again earned as much as he had on the waterfront. ${ }^{59}$ One watersider described his new work situation succinctly: "I went to a worse job, with worse conditions and less pay". 60

Other family members' had their pattern of work affected by the stress of repaying family debt, particularly young adults who had not yet left school. Yvonne Grove had hoped to go to university, but in 1954 she had to leave school and find work: "I knew if I could go to work it would bring some money into the house" ${ }^{61}$ Her father was Toby Hill who had been the Secretary of the NZWWU and had been blacklisted. Marilyn Bowman and Bruce Malcolm, whose fathers were both watersiders, also described giving up their dreams of university to start paid work, because of their families' financial situation. ${ }^{62}$ Some women who had taken up paid work as a short-term strategy during the dispute continued because of their family's financial position. Maureen Fairey remembered her father, who was an Auckland watersider, arguing that no wife of his would ever take paid work, but financial necessity changed his mind. Fairey's mother had to take paid work during the lockout, and continued this work afterwards. She resented having to do paid work, and resented her husband for not earning enough money in his new job, but it was her decision that paid work was a better option than not having that income. ${ }^{63}$ Ida Thompson also continued her work as a

\footnotetext{
${ }^{56}$ Strike Returns, Department of Labour, 1951, AANK-W3285-7, ANZ. Some watersiders were rehired later on after strikebreakers left, but this varied significantly between ports. For a detailed discussion of the situation in Lyttelton see: Wayne Townsend, "From Bureau to Lockout: Lyttelton Waterside Workers 1920s to 1951" (MA University of Canterbury, 1985), 287-90.

${ }^{57}$ Meade, "New Zealand Waterfront Unions," 48-50

${ }^{58}$ Dennis Brown interview with Grace Millar, 12 October 2010; Conan Doyle interview with Hugo Manson, 1986, OH-Coll-011881, OHC-ATL; Rev. J. S. Somerville, 'notes on black-listed freezing workers', [1952], 396/39118, DC 3/5; R. Muir to Minister of Labour, [November 1953], AANK-947-W35803/3/2022, ANZ; Peter Franks, "Hill, Tobias McGlinchy," in Dictionary of New Zealand Biography (2012); Tom Bramble, ed. Never a White Flag: The Memoirs of Jock Barnes (Wellington: Victoria University Press, 1998), 233-36.

${ }^{59}$ Ian Church interview with Grace Millar, 11 February 2011; Maureen Fairey interview with Grace Millar, 5 July 2010.

${ }^{60}$ Anna Green interview with watersider, mid-1980s. Anna Green gave me access to these interviews on the condition that I do not identify individual interviewees. Further information about her interviewees can be found in her work: Green, British Capital, Antipodean Labour.

${ }^{61}$ Melanie Nolan, "Shattering Dreams About Women in the Lockout," in The Big Blue: Snapshots of the 1951

Waterfront Lockout, ed. David Grant (Christchurch: University of Canterbury Press, 2004), 76.

${ }^{62}$ Pete Gorman, Wharfies: The $W$ atersiders of Port Chalmers, (Variant Media, 2007); Nolan, "Shattering Dreams," 76.

${ }^{63}$ Maureen Fairey interview with Grace Millar, 5 July 2010.
} 
cleaner after the dispute. She described her decision to do so in terms of the dispute: it had depleted the couple's savings and she was doing her part to build them up again. ${ }^{64}$

Debt affected families for many years after the dispute, because it took so long to repay. The best evidence of the history of debt repayment is from the Seamen's Union. Twelve debtors have a payment marked "final payment" in the Seamen's Union receipt book. The first seaman to repay that debt in full was J. Devitt; he paid off the last of his debt in October 1952. ${ }^{65}$ Five other seamen repaid their debt in full in 1952. The next final payment occurred in 1955 and three people made their last payment in the 1960s. J. Stevens was the last to repay his debt in these records, in April $1964 .{ }^{66}$ Seamen were not representative of other workers involved in the dispute, as their debt was to the union and they were paid wages on leaving a ship, rather than weekly. However, these differences made seamen more able and motivated to pay off debt, not less. Seamen were certainly not the only people repaying debt accumulated during the dispute into the 1960s.

Scant evidence survives about families and individuals failing to repay strike debt. Evidence from the dispute suggests that eviction and repossession were used rarely if at all, in those five months. ${ }^{67}$ Bankruptcy, mortgagee and other public records of debt defaulting are difficult to connect to the dispute. The high turnover of workers on the waterfront at the end of the lockout means that most of those who described themselves as watersiders in 1952 or 1953 would not have been working on the wharves in 1951. However, isolated evidence of people suffering significant losses due to their inability to repay debt does exist. Jimmy Hewitt, a Wellington watersider, described losing a deposit on a house during the dispute. ${ }^{68} \mathrm{Mr} \mathrm{R}$. Cecil had been an Auckland watersider and he was served eviction papers in July 1953. He had been behind on his rent since the dispute, and had had another period of unemployment when his wife died and he had to care for his children. ${ }^{69}$ He was still in debt and fighting eviction two years after the dispute ended.

Few adults, even those who go into detail about what they owed, talk about the process of repaying debt, or how long it took, but children's accounts give a glimpse into how their family life changed once their parents had paid off their debt. Two men who were boys during the dispute tell very similar stories of a time when the debt was paid off. Kevin Ford said: “Things started to pick up a bit. That's when we started to go to the movies - I know that - we never went to the movies while... for years. Then all of a sudden we were going the movies. ${ }^{, 70}$ William Dougherty, whose father was a watersider in Port Chalmers, also talked about only being able to go to movies when he was older. ${ }^{71}$ Their stories stand as acknowledgement that the point where debt was paid off existed, and made a significant difference to the economic lives of families

\footnotetext{
${ }^{64}$ Ida Thompson interview with Kerry Taylor, 1995, OHColl-0861, OHC-ATL.

${ }^{65}$ New Zealand Seamen Award, 16 December 1950, New Zealand Awards Agreements \& c., made under the Industrial Conciliation and Arbitration Act, Apprentices Act and the Labour Disputes Investigation Act, 1950, Vol.50, 3651.

${ }^{66}$ Auckland Seamen's Strike Committee - Financial records, 80-307-22/03, New Zealand Seamen's Union Records, ATL.

${ }^{67}$ At a meeting in May the Auckland branch resolved to fight the next eviction, but there was no further discussion, NZWWU Auckland Branch, Minutes of Special Meeting of Executive \& Chairmen of Committees, 7 May 1951, 94-106-11/01, Roth Papers, ATL. For SAC unwillingness to evict see: 'Minister explains rent demands made at Miners' hostel', 22 May 1951, (R10074973), ADMO-21007-W5595/125/9/20/6, Part 1, ANZ.

${ }^{68}$ Jimmy Hewitt interview with Gerry Evans, 1 February 2000, copy in author's possession.

${ }^{69}$ Hon. Secretary to Mr J. S. Reynolds esq., 6 August 1953, Box 2, Folder 1, 89/203, Mitchell Papers,

Auckland Museum.

${ }^{70}$ Kevin Ford interview with Grace Millar, 13 February 2011.

${ }^{71}$ William Dougherty interview with Grace Millar, 11 February 2011.
} 


\section{The Social Meaning of Debt}

Debt shaped relationships where credit had been extended and accepted. In 2011, David Dick, the son of a locked-out watersider in Port Chalmers, was completely committed to using local shops, rather than shopping in Dunedin, because local shops had extended credit sixty years earlier. ${ }^{72}$ Kevin Ford described buying groceries from another grocer a decade after the dispute, and his father's reaction:

Mum said "no Kevin got these from the grocery store on the wharf. They're a lot cheaper than Charlie Denny" - that was our grocer - and Dad took one look at me one look at my mother, picked them up and he said come follow me. I followed them out and he threw them in the rubbish bin and he said that if I bring anything home like that again I'll be put in the rubbish bin and I'll be out the gate. He said 'the grocer carried me for three months and half them bastards down there and they started a store up against him'. He wasn't a very happy chappy. ${ }^{73}$

This incident happened in the 1960s. Debt and credit extended during industrial disputes shaped social and commercial relationships within working-class communities for decades.

Working-class people's identity and sense of self could be tied up with the way they managed debt. Johnny Mitchell saw his wife's commitment to repaying debt as part of her character:

[The grocer] gave us credit right through, and he always bragged that it was the Mitchell family who always paid their bill at the end of the dispute, some of them didn't, but Lorna paid up every penny that he gave us credit for.

[Interviewer: it's essential that a man can hold his head up high for everything.]

Yes, Lorna was that kind of person. ${ }^{74}$

As has already been discussed, Tom Gregory identified as someone who never went into debt even though his landlady gave him credit during the dispute. ${ }^{75}$ Gregory and Mitchell were both comfortable with the way their family had managed debt and the dispute and discussed it with some pride and satisfaction. Maureen Fairey showed the other side of this pride in her interview. Fairey was aware that her parents had gone into debt, because her mother told her about it: "She told me that at the end of the six months or so she said we had absolutely nothing and we were in debt." ${ }^{76}$ Debt contributed to on-going bitterness within her family: "And my mother was a very proud woman, it would have really made her very angry. But she said to me that my father never really went without too much you know - it was her - and she had to make do for us kids really." 77 Here

\footnotetext{
72 David Dick interview with Grace Millar, 11 February 2011.

${ }^{73}$ Kevin Ford interview with Grace Millar, 13 February 2011.

${ }^{74}$ John James Mitchell interview with Douglas Crosado, Ray Grover and Bert Roth, 1977-1988, OHInt0219/1, OHC-ATL.

75 Tom and Pat Gregory interview with Grace Millar, 20 December 2010.

${ }^{76}$ Maureen Fairey interview with Grace Millar, 5 July 2010.

77 ibid.
} 
Fairey links the debt, her mother's emotional response to the debt, and conflict within her parents' relationship. In order to talk about the 1951 waterfront dispute, Fairey has to explore the relationships within her family, which underscores the importance of industrial conflict in shaping her family's life.

\section{Class-Consciousness and Family Strike Debt}

Examining the social and economic cost of strike debt also gives a much wider understanding of David Camfield's question; what does a strike mean for the working class movement? Elizabeth Faue argued that the family is where people first experience class. ${ }^{78}$ A significant industrial conflict like the 1951 waterfront dispute shaped how the participants and their families experienced class. One of the reasons that it is difficult to uncover the role of the family in class consciousness is that it may be the first place people experience class, but it is not the last. I interviewed thirteen children whose fathers were locked out and on strike; they were in their 60s and 70s. How they discussed the impact 1951 had on their family, how they understood 1951, and how they articulated class in their interviews were all affected by the events of 1951, but they were also affected by their different experiences over the following 60 years. Four of the men I interviewed had followed their fathers and spent the bulk of their working life on the waterfront. ${ }^{79}$ The way these men talked about the lockout reflected that, like their fathers, they had a conception of class and industrial disputes shaped around decades of wharf work. For example, Kevin Ford, who was still working on the Timaru waterfront when I interviewed him, had clearly absorbed his father's message about debt, responsibility and industrial disputes. ${ }^{80}$

Maureen Martin's interview, from which this article gets its name, provides a way of exploring in more detail how 1951 affected class consciousness within a family. In her relatively short interview with her grandson she recalled her experiences as the wife of a freezing worker. This interview was archived in the Alexander Turnbull Library alongside an interview between Martin and her daughter-in-law Pip Desmond about the depression (Desmond intended to interview Martin about 1951, but was not able to do so before her death). ${ }^{81}$ Martin's grandson had grown up in a very different world from the one his grandmother described. His father had been the first in his family to go to university, so his family's class position was very different from Martin's experience. ${ }^{82}$ In addition, the interview took place in the context of seven years of successive governments dismantling the post-war welfare-state consensus, and weakening unions. ${ }^{83}$ Martin uses her narrative of 1951 to ensure her grandson has an awareness of the struggles she was part of, and the world view that sustained them. She explains solidarity and ensures her grandson is aware of her support of the strike, particularly when it comes to the importance of not crossing a picket line. When her grandson asks if it ever looked as if her husband was going to have to go back to work, she replied: "Oh no, you would never stop the strike, no, no good heavens, I'd have left him. You know what the name is for someone who stops the strike don't you? - a scab." ${ }^{\prime 84}$ Here she is asserting her own class-consciousness

\footnotetext{
${ }^{78}$ Elizabeth Faue, "Retooling the Class Factory: United States Labour History after Marx, Montgomery, and Postmodernism," Labour History, no. 82 (2002): 113.

${ }^{79}$ Kevin Ford interview with Grace Millar, 13 February 201; David Dick interview with Grace Millar, 11 February 2011; William Dougherty interview with Grace Millar, 11 February 2011; Robert Hannah interview with Grace Millar, 11 February 2011.

${ }^{80}$ Kevin Ford interview with Grace Millar, 13 February 2011.

${ }^{81}$ Maureen Martin interview with Liam Martin, September 1999, Transcript, OHColl-0458/1, OHC-ATL.

82 Pip Desmond, Trust: $A$ True Story of Women and Gangs, (Auckland: Random House, 2009).

${ }^{83}$ Keith Sinclair and Raewyn Dalziel, A History of New Zealand, Revised Edition ed. (Auckland: Penguin Books, 2000), 334-57.

${ }^{84}$ Maureen Martin interview with Liam Martin, September 1999, Transcript, OHColl-0458/1, OHC-ATL.
} 
- and using the narrative to ensure that her grandson understands the importance of never being a scab. Martin used narratives about 1951 to communicate her understanding of working-class values and behaviour to her family members, just as Kevin Ford's father had.

Within Martin's family 1951 could not just function as an exemplary narrative; its economic legacy was too significant. As quoted in the introduction, the debt from 1951 was not something that her family recovered from. Martin explains what steps they took in order to avoid another catastrophe: "he got his job back and the company wanted him to join the staff, which meant if there was ever another strike he could stay with the company and get paid, he didn't go out, and he felt he had done his share, so he did join." ${ }^{85}$ Although she is using the narrative of the dispute to raise class consciousness in her grandson, as a result of 1951 her husband decided to actively change his class position, so he would not suffer the same hardship again. Martin's interview with her grandson shows some of the complex and hard to access legacies of 1951 for the working-class movement. For those involved, 1951 existed as a story and a legacy, and an economic reality that had to be managed.

\section{Conclusion}

This article has shown that for most families the 1951 waterfront dispute did not end in July, but just entered a new phase, as it still had to be paid for. During the dispute family finances were a concern for the whole branch, as they could drive a watersider to work as a strikebreaker. In the first week of July 1951, the Auckland relief committee wrote a report of their work so far, and included a discussion of how they saw their role if the dispute continued:

If dispute concludes on Friday as suggested by Mr. Drennan there will be an approximate period of three weeks for the rehabilitation of members costs will be in the same proportion as goods will be more plentiful and members unable to obtain work are entitled to a fuller ration than previous. On that basis a sum of approximately $£ 4,000$ will be required as credit firms, landlords, etc. will expect and demand full payment of commitments and not on a meagre, partial basis as at present. ${ }^{86}$

This statement is one of the few union sources that acknowledged that the effects of the conflict would last beyond its official end. Once the dispute ended, individual families' financial positions were no longer a collective union concern. In fact, the Seamen's Union became a creditor on its members. During the 151 days watersiders were locked out, the costs of the dispute were a collective responsibility, but at the end of the dispute, responsibilities that had been collective reverted to individual families. Relief organisations continued to exist for a few weeks, but then families' survival was pushed back behind closed doors.

Noting that strikes and lockouts were paid for by debt is not a new observation. While discussion of the aftermath of strikes and lockouts is rare, as shown in the introduction, historians have described the use of debt by striking workers and their families. However, historians have only very briefly discussed the impact of strike debt

\footnotetext{
85 ibid. Martin's family was not the only to make this decision; Charles Bullock became a mining deputy so that he would not have to go on strike again, Cora and Charles Bullock interview with Jamie Mackay, 23 March 1992, OHInt-0020/13, OHC-ATL.

86 'Report', Relief Committee, New Zealand Waterside Workers' Union (Auckland Branch), 94-106-11/06, Roth Papers, ATL.
} 
on families and communities. Labour historians have often marginalised the aftermath of industrial disputes. In doing so, they have implicitly accepted that the consequences of a dispute were the concerns of individuals and families, not history. Prolonged lockouts and strikes have an impact on people and communities that last long after all the workers have returned to work, and if histories of industrial disputes ignore that they reinforce the privatisation of costs after a dispute. 